\title{
MACHADO DE ASSIS, MORAL IMAGINATION AND THE NOVEL
}

\author{
José Luiz Passos \\ University of California \\ Los Angeles, Califórnia, Estados Unidos \\ In memory of Richard Wollheim
}

\begin{abstract}
The article discusses the premise behind binding literary value to the ability a work has to yield socio-historical information, prevalent in recent criticism on Machado de Assis. It argues that the body of Machado's work shows an increasing ambivalence regarding the links between imagined lives and history, thus proposing that in his late writings the matching between things real and things represented is a rhetorical and melancholy gesture of great insight. In order to illustrate the prevalence of moral imagination as object and technique in Machado's late novels, the author highlights a few points of contact between Machado de Assis and Henry James, contemporaries and akin in their literary sensibilities.
\end{abstract}

Keywords: Machado de Assis; realism; moral imagination; Henry James.

\section{Machado de Assis, imaginação moral e o romance}

Resumo: $O$ artigo discute a premissa, dominante na crítica machadiana recente, de que o valor de uma obra literária esteja diretamente relacionado à sua capacidade de prover informações sócio-históricas, argumentando que o conjunto da obra de Machado de Assis mostra uma ambivalencia crescente no que se refere a essa equivalência entre vida imaginada e história, e propondo que, nos grandes romances do autor, a principal fonte de uma percepção melancólica do mundo está na consciência de que o gesto de relacionar coisas reais a representações é trama retórica. Para ilustrar a prevalência da imaginação moral nos romances tardios de Machado de Assis, o autor destaca alguns pontos de contato entre Machado e Henry James, contemporâneos e correlatos em suas sensibilidades literárias.

Palavras-chave: Machado de Assis; realismo; imaginação moral; Henry James.

Throughout the twentieth century, and particularly after the 1950s in Brazil, we have come to believe that the connection between narrative meaning and national life is central to understanding literary realism. There is an under-examined assumption that, regardless of the author's intention, the representational content of our major works are key aspects of Brazil's history, social identity, and class structure. This is particularly the case when critics assess works whose depiction of social and private 
life ostensibly resemble what we believe took place in the past. In this sense, realism seems to yield truth making by means of including people, events, and relations that bear a considerable similarity with our world. A common assumption about the reader's relationship with these novels, for instance, is that when we read them, and understand them properly, they are able to convey specific information about the author's world and possibly about our own as well. Most interpretations of novels as clear-cut bearers of social representations share this claim even when they adopt a more restricted version of it. And the case seems all the more appealing when the work in question is a realist novel.

Behind this argument lies the belief that a picture of how society works can be retrieved from creative narratives, for under the realist convention - some have argued - novels resemble the world they intend to depict. And if we interpret them the right way, we will get both the work and a picture of its referent. A double prize is at stake, and this is very tempting. Indeed, the assumption seems to be validated when we consider that literary works are good examples of how we may use language to represent our own experience. Even though this picture is fundamentally flawed, it has a nice history of its own and remains a major standpoint from which critics, historians, and sociologists have approached the relations between Rio de Janeiro society during the Second Reign (1840-1889) and the writings of Machado de Assis (1839-1908).

Though few literary critics would now subscribe to all the implications of such a picture of literary representation, the major interpretations available about the significance of Machado's novels are still tied to the same set of assumptions that underlie this view. One can find it in the recent surge of insightful new studies on Machado's crônicas and his early novels, championed by Sidney Chalhoub. One can find it again in Roberto Schwarz's reelaborations on his theory of literary form and social structure in nineteenth-century Brazil, as well as in John Gledson's emphasis in identifying Machado's plots and characters on real-life people and events. Yet their arguments must be defended and proven if we are to maintain our expectations about the resemblance between work and world. On the other hand, if this is not the case, the premise of binding literary value to the ability a work has to yield socio-historical information must be revised. My point is fairly simple and more specific than it might appear. The Posthumous Memoirs of Brás Cubas (1881), for example, has been 
assessed and valued in terms of its depiction of contemporaneous social life. There is no doubt that this is one of the possible games we can play with the book. But we should consider whether this is the most interesting way we can relate to these kinds of objects.

In "Pierre Menard, Author of the Quixote," Jorge Luis Borges poses an interesting riddle about how our beliefs concerning the author's world and his powers to represent it shape the meaning of an artwork. Pierre Menard, whose career is being eulogized by an anonymous narrator, has spent most of his life trying to write pages of Cervantes's Don Quixote without simply copying it. The point made by Borges's narrator is rather appealing. He presents us with two excerpts - Cervantes's and Menard's. The words coincide, but Borges's narrator argues that their meanings diverge considerably. Despite the limited outcome of Menard's efforts, the narrator points out he is more powerful then Cervantes, for his text cannot be understood as the expected byproduct of his own time. Rather, it is the result of a mind that four centuries later was able to deliberately capture Cervantes's relevant inner feelings and thought processes in order to replicate the Spanish Golden Age text. Borges invites us into a world in which we are initially asked to accept the reasonable hypothesis that texts are the outcome of specific personal, social, and historical settings. This is the case of Don Quixote. But he goes further. Borges's narrator implies that in the case of Menard's texts those conditions governing the production of Cervantes's work can eventually be mimicked by another mind, provided that this mind is able to conjure up something of the experience that brought about the original. The fragments that match Cervantes's text supposedly testify to a super-human ability to evade historical necessity. Borges puts forth an ironic view of meaning. How many texts are we left with - one or two? The narrator implies that there are indeed two different works, for they result from different worlds. A tantalizing effect springs from the linguistic coincidence of both excerpts; their equivalence produces the vertigo of two unidentical minds conflated in the expression of a very complex object - at least within the context of Borges's deceptively simple bibliographical report.

The point of interest for our discussion of history and moral imagination in Machado is simple. Cervantes's text resembles his own world, whereas Menard's resembles Cervantes's. To put it differently, the referent of both texts is the same but 
their sense is different, because the histories of their production and use differ radically. Borges's story plays with readers' expectations regarding necessity and possibility. Borges breaks with the usual sense of unity between world, artist, and work. Menard's imagination seems to overpower historical necessity - or is it a hoax? For Borges's narrator, Cervantes is a great author but Menard is a demigod - for only the latter is able to step out of his circumstances and defy our understanding of human creation when he chooses to imagine what is needed to write fragments of how another human being perceived his world and described it centuries earlier. Menard's most important creation is then a disembodied inner self, extricated from history - a self that is able to mimic past shadows of experience and engender traces of Cervantes's presence in the world. In this sense, Menard in his utter implausibility is at the same time the ultimate realist and the only perfect historian the world has ever known. He captures the past to the point of replicating fragments of it. He matches the experience of another human being to the letter, rebuilding a ruin. I will argue that the pairing of realism and history - carried out as the struggle of individuals who seek to fit into a world in which they don't belong - is a melancholic move ubiquitous in Machado's writing. But for now let's save Borges's template for a lesson about the seductions of interpretation.

Not everything is the case. Some things might have been the case, and others will necessarily be the case if and only if they do obtain. Consider the fact that I can use the English language to describe what never took place. I can imagine two people having a conversation about how to kill a third one, or how to make a cake. I can draw your attention to a state of affairs that has never obtained in our actual world. Yet for some reason it feels easier to speak of presenting something than to speak of representing the same thing. Show me a dog. You point to one on the street. You can be right - but you can also be wrong, say, if you point to a fire hydrant instead. However: Represent a dog. I can draw one, and then a "better" one; I can take a picture of another; I can describe the yellow pug of my childhood, etc. In what sense could I be wrong about my imagined dogs? In what ways could they misrepresent an actual dog? They could. If I decide to elaborate on my yellow dog, there are ways to "bring it back." There are ways I can get it wrong too. If I say it had three heads, I will be talking about Cerberus - not my dog. And yet Cerberus is undoubtedly a dog; and this is at the same time wonderful and reassuring: that I can use a dead yellow pug from my past to 
wonder about Cerberus's properties as a dog in between two worlds. I am a big fan of Cerberus, yet I cannot really say I miss him the same way I miss the yellow pug of my childhood. Now we are getting closer to what I call realism as a grammar for "getting things" and conveying them to others, for if I want to give you an idea of the dog I miss I can draw a "better" dog (with one head rather than three) and I can link it to my pug, saying "this is it, I got it right this time." There will be a moment when other people, unaware of my actual pug or intentions to depict it, will be able to see a pug on a page of paper. When this happens, I will have succeeded in bringing it back as a pencil sketch or through descriptions in English language.

We can discard the personal anecdote and maintain the process of impersonating objects and relations. Realism is a melancholy grammar we can deploy to imaginatively conjure up things "as they are" or "as they happened" in time. It is in the latter sense that the historical imagination and the writing of history itself belong in the realist mode. Matching someone's representation of the real world is paramount here; seeing it as a matching process is even more important. The real trick is neither in someone's intentions alone nor in an actual comparison between thing and representation - the trick is in matching as a grammar game that allows for identification, acknowledgement, and sharing. The assumptions behind some of the major interpretations of Machado's writing are based on a supposed homology between literary form and social structure - or between style and historical information. In either case, represented history becomes a function of Machado's writing.

It is through the matching practice of a game played with others that realism builds up its grammar - and not in an abstract homology of structures or the intentional coincidence between things real and represented. The awareness that this gesture is a trick is the source of melancholy. Consider Bento Santiago's efforts to match his childhood house with a new one in old age; his feeling of marital bliss with his later sense of betrayal; his friend with his wife, etc. Bento is a realist and a historian precisely because of the allegorical nature of his matching imagination. He tricks himself into becoming a "matchmaker" and correlation maker who hopes to erase his own footsteps while pretending not to be playing that game.

If a friend of mine decides to represent my yellow pug he can get closer to it by trying the best he can to match pugs in general through drawings or descriptions of 
it. But to match my pug he would have to turn into Pierre Menard and replicate my sense of the dog, my imagination of it. If my friend succeeds he becomes at the same time the ultimate realist - for matching so intangible a dog - and the perfect historian, for his representation of a relation between an individual and his sense of a world in the past: in other words, my memory of my dog; my experience of it; my sense of a life with it. I am pushing the case to its limit here. My point is that in creative literature we can go one step further when considering world building - we can pretend to have the experience of others and match their minds and take pleasure in doing so.

When Machado published the first version of The Posthumous Memoirs of Brás Cubas in installments between March and December of 1880 in the Revista Brasileira, he gave rise to an enduring problem for literary historiography. The Brazilian novel had been thus far deeply committed to the representation of the particulars of national life. Together, the thirty-eight novels published by Joaquim Manuel de Macedo and José Martiniano de Alencar had strongly relied on the depiction of a recently independent nation that was eager to see itself as the subject matter of a fairly recent genre in Latin America. The Brazilian romantic novel served as an instrument of self-assurance, driven by readers' enthusiasm for fanciful plots interwoven with references to landscape and national history.

The years between the 1860 s and the 1880 s brought a slow decline in slave labor, the first challenges to the monarchy's exclusive political alliance with traditional agrarian elites, and the first signs of decay of coffee production in Rio de Janeiro. Moreover, from 1868 on the rise of Abolitionism and Republicanism of either romantic or positivistic inclination posed a more organized ideological challenge to the Second Reign. Such demands for structural change would be paralleled by the increase in European and Asian immigration rates, and the adoption of deterministic theories by intellectuals of the so-called generation of 1870 .

The writing of The Posthumous Memoirs is contemporary to this process of modernization. Machado's novel, nonetheless, depicts the first half of nineteenthcentury Rio and not the transformation just briefly described. It avoids the actual economic and social change following the end of transatlantic slave trade in 1850 and the urban expansion and reshaping that the Court would undergo during the last quarter of that century. Furthermore, the novel's narrative frame is surprisingly fantastical. Brás 
Cubas is a dead narrator whose nostalgic reminiscences, ironically told from the afterlife, lead the reader through a succession of interpolated allegorical episodes, starting with a delirium in which the hero rides a talking hippopotamus to the origins of historical time. Machado seems to bypass some of the fundamental premises of the very style he is known for having introduced in Brazil: the realistic portrayal of contemporary society, aimed at the indictment of the moral and physiological dysfunctions of modern social life. Contrary to most contemporary realist or naturalist novels, The Posthumous Memoirs displays an unsettling and satirical anachronism in a time when Brazilian intellectuals agreed on an optimistic and often naïve trust in scientific discourse as a key for national progress. Machado's novel did not seem to portray prosaic national life in full detail, as Manuel Antonio de Almeida had done twenty-five years earlier in Memoirs of a Militia Sergeant. Besides, Machado's novel apparently refused to serve as a source of fanciful and serene entertainment, as Joaquim Manuel de Macedo's courtly love plots were read. It also denied the reader any sign of moral or civic instruction, as José de Alencar had attempted to do throughout his works. Finally, The Posthumous Memoirs did not seem to bring about what naturalists such as the early Eça de Queirós and Aluísio Azevedo had intended: the overt exposure of social maladies and prejudices.

By the end of the 1870s, while the influence of the recent European scientific theories started to grow stronger in Brazil, Machado was forty years old and author of almost a hundred short stories and four novels. Without exception, these early narratives depicted the protagonists' quests for rising to a life of moral independence and social dignity. Some of these pursuits were bound to fail as a result of the heroes' and heroines' own obsessions with their hidden past. Despite their differences, what is common to Machado's first four novels is an elaborate relationship between shame and dissimulation, between moral awareness and make-believe. These protagonists' ability to disguise their true motives and perform an imagined self represents the only possibility of overcoming the deep sense of humiliation that is invariably linked to their histories. The case of Iaiá Garcia (1878) is emblematic, because it leads us to Brás Cubas and Bento Santiago.

It is New Year's Day and Luís Garcia, Iaiá's father, is organizing his papers in preparation for a trip. He spends that afternoon discarding old letters and newspapers 
in an exchange with fading memories of his past. Suddenly Luís Garcia finds an old letter sent to him by a young friend then in love with Estela, his current wife. He is apparently unaware that his friend's former love and his current wife are one and the same person. However, his young daughter Iaiá watches Estela, her stepmother, disguise her feelings when Luís Garcia shows her the letter. They are both unaware that Iaiá is observing them:

Perhaps opposing forces were struggling within her [Estela]; or it was her past that was merging from the shadows of time, with all its bright or dark colors, its hidden and never reveled pleasures, and at the same time its sorrows and strength... Opposite them Iaiá's eyes were fixed on her step-mother... She saw her take the letter with a shaky hand, saw her become even paler; she saw her confusion and perplexity. Why the perplexity and confusion?... Iaiá looked at first with curiosity, then with surprise, until her eyes shone with wisdom and perception... Iaiá guessed Estela's past, but she guessed even more. She strode rapidly over reality until she hit upon the possible... Behold the result. Estela was not to blame. What was casting such a shadow on the present situation was an incident from the past, but the scene of commotion was enough to disturb the stepdaughter's spirit and to drop therein the first germs of the knowledge of evil. What if she were guilty? ${ }^{1}$

In Machado, shame and guilt are a function of the past. They are one's awareness of having had a past, and this is the first possible step into history proper. The chapter is a good example of Machado's art in the pathos of introspection and calculating if troubled resignation. Estela's dilemma exemplifies the fates of his previous heroines of shame and polite deceit. This time, however, she is being watched, and Iaiá's imagination of her stepmother's possible mischievous deeds is enough to enrich and deepen Iaiá's own moral perception of the world. Such a move represents an important variant within Machado's art of character construction. Before Iaiá Gracia his heroines had to rely on the adversities of their own upbringing and unstable social position in order to wield an unusual ability for imagining themselves differently and putting forth elusive personas.

In the novel, nothing happened in the past and not much happens that evening, and yet a new world is revealed as the result of an elusive and fleeting intrusion of the past upon the present. Iaiá's guess about Estela's origin and current state

\footnotetext{
${ }^{1}$ ASSIS, Iaiá Garcia, p. 85-88.
} 
of mind is a lesson in Menard's practice of understanding the lives of others without actually living them. In Machado's world, melancholy is a function of how one might attempt to ground the self in history, and understand or restore what has past. In a sense, that was what young Iaiá learned after observing how other people interact and hide elements of their past. As with Catherine Sloper in Henry James's Washington Square and Balzac's Eugénie Grandet, these young women learn the hard way the cost of other people's expectations about them. The issue of intentionality and believable motivations in Machado's work is often presented to the reader as a question of masks and dissimulation - life framed by a form of double-consciousness. These are ironic fictional worlds in which the characters' and narrators' moral beliefs clash with the reality that encircles them. Such clash brings about a world of deceptive ethical fluctuation. Machado's first four novels depict the protagonists' quests for integration into the Rio elite society. In a similar fashion, The Posthumous Memoirs would also gaze backwards. These novels are set between the $1850 \mathrm{~s}$ and $1860 \mathrm{~s}$, distant from the time of writing some twelve to twenty years. They also look retrospectively in a narrative sense, for their plots revolve around the vestiges of the protagonists' past; people who constantly remind themselves of what they have done or where they came from. Individual self-awareness becomes a melancholy link between past and present. Machado allows his mature protagonists to become narrators, and in this new capacity, these characters will sometimes give the impression that the history of their selves matches the development of Brazilian political life. Yet reading the body of Machado's work shows an increased ambivalence about any direct equivalency between imagined lives and history, one that his early twentieth-century novels will take to its furthest degree.

The nine novels published by Machado between 1872 and 1908 constitute a progressive meditation on self-knowledge and deceit. In virtually all of them, the protagonists come to terms with their sense of self-worth vis-à-vis an incommensurable desire for social climbing and disguised self-indulgence. As much as Don Quixote and Anna Karenina, Machado's novels explore how individuals deal with their longing for a different life, a life consistent with what they believe they deserve due to the power of their imagination. However, contrary to Cervantes and Tolstoy, the world Machado portrays seems almost blind to true friendship or redemption. It is a world in which the 
endless scrutiny of self-interest and the parallel mocking of benevolence have nearly obliterated trust. No other body of work within Brazilian literature bears a comparable reflection upon loss, malice, and their sublimating attempts at restoration.

Machado's greatest contribution to the Brazilian novel is the conception of heroes and narrators whose malicious worldviews are self-exposed while still holding on to an overwhelming sense of bittersweet nostalgia and propriety. The world opened by Machado's realism in 1880 with the publication of The Posthumous Memoirs allowed the Brazilian writer to set the pace with literary modernity by claiming an interestingly anachronistic relationship with European sources - often carried out through parody, mocking borrowings, and ironic adaptations. Machado's view of human values is not of a world in distress or at the brink of any disorder; rather, it conveys the idea of an orderly universe populated by individuals harmful to one another because of their inescapable imaginings of foul play and relentless drive for power and avoidance of responsibility.

So, how does Machado's project of interweaving melancholy litanies of self-assessment and Brazilian history at large reach an end? One of the most revealing differences between the novels Machado published until 1899 and the last two he wrote during the first years of the twentieth century is that the latter depict an often conscious fabrication of illusions and divinations about the present, whereas the former are concerned with individuals who tell the stories of their lives in their attempts to achieve full control over other human beings. Brás Cubas, Quincas Borba, and Bento Santiago observe themselves as history; Machado's last narrator, counselor Ayres, places others in history. As way to bring this overview to a close, I would like to highlight a few points of contact between Machado and a literary sensibility akin and contemporary to his: Henry James.

The literary and personal form of a long-lived life, worn out but nonetheless filled with a deep sense of yearning, served both Machado and Henry James as a way to enter the twentieth century. Their furthest efforts at subtlety in characterization blending imagination, history, and autobiography - are found in two of their very last novels, The Ambassadors (1903) and Counselor Ayres' Memorial (1908). Their heroes are diplomats - one actual and retired, the other putative and manqué. Heralds of other times and spaces, they bear that uneasy, valuable foreignness which in itself invites us 
to think about the requirements of cosmopolitanism, a risky inner step toward difference and at the same time a path to be followed in the company of others. A new sense of promise unfolds as James and Machado guide readers through a subtler sense of accomplishment; not of the writers themselves but an accomplishment that belongs to a new kind of hero whose quest is, simply put, the sheer pleasure of gazing at the intricate mesh of possibilities for leading one's life.

The hero as a diplomat is not strange to the novel. And unlived possibilities are without a doubt a key aspect of our moral imagination, literary or otherwise: the outcome of the mind's eye that holds together one's sense of self. But when these two aspects are combined, the trope of a well-traveled go-between whose methodical mindset aims at understanding love and love lost, provisional exile and the burden of homecoming, all this suddenly becomes a challenging way of framing the protagonist's awareness of his own shortcomings against the landscape of a fuller kind of life, which is now the exclusive country of others. Something of a useful parallel was already set in motion when both writers decided to avoid placing their heroes' lives as the object of narrative plot, instead drawing on them as a standpoint through which elusive affairs among younger couples and the elite unfold and are evaluated, eventually becoming a full-scale mirror. These diplomats witness an interesting blend of love and history; love that in some of their previous work had seemingly extricated men and women from history. And they finally make this complicated form of life - now lived through only vicariously - a full-fledged art of resignation.

Yet both The Ambassadors and Counselor Ayres' Memorial show that resignation, when paired with meticulous attention to others, comes with considerable insight, even when such attention is uneasily guided by a jealous gaze at those who live more richly or sensually than the onlooker himself does. The shadow of sadness that unfolds before the readers of James and Machado's last novels is indeed a sign of things exposed and altogether realized by their heroes, as they take in human life imagined at full throttle. The concurrence of retirement and diplomacy then becomes a remarkable strategy for providing an improved picture of openness toward difference in living, even if life itself is now closer to the end. Ultimately, for lack of a better alternative, Lambert Strether and Counselor Ayres go back to their places of origin, places where they can no longer belong. But such impracticalities of love and homecoming - and for 
that matter of any fuller future - for them is ever more encompassing in its disclosure of an even wider range of possibilities; it is now a framework for others' fulfillment. The measured withdrawal of both diplomats eventually presents itself as a scale-model for a full-fledged engagement with communities about to step into the challenge and disenchantment of change. In this sense, conflicting mores and moral displacement are at once a function of weariness and a source of delightful insight. They are also the result of a very specific relation between the transatlantic footing of these protagonists and modernity itself, for in the end the scrutiny of others - some of whom we hardly get to see - provides them with those imaginary but defining boundaries within which one can chart a properly individual path. The bonds of possibility that James and Machado place in the hands of Strether and Ayres are for the Americas - particularly in its unavoidable relation with European art - an inconspicuous way to bridge narrative realism into the twentieth-century.

In both cases, the seemingly distant point of view, fleshed out as a game of elusive intentions and estrangement from the homeland, yields a thoroughly dynamic sense of self: a self whose dislocation brings about the enhancement of experience. Such a puzzling form of metamorphosis belongs only to the vigorous observer. It is a condition shared by these diplomats. This is how we can begin to understand what it is to lead a life as an attentive New World reader, and how to make such a metaphor something of an aid: a gesture that if mindfully sought out can take us closer to what might become accurate equipment for living.

Such promise of reading, as I have sketched from the outset, must be taken into account whenever we think about our engagement with a work that expresses someone's growing sense of having become more experienced in reading and seeing and understanding other people. The parallel between Strether and Ayres tightens as one considers their stories as a fall from grace in exceeding slow motion. And set at the peak of both writers' careers, when they were often referred to as masters of their trade, the choice they made of depicting disenchantment as a spell - and old age as competence in reading people - can only mean that the task of writing novels for them, at that particular moment, turned inside out. The trust in their own capacities went hand in hand with confidence in autobiography, and what followed for both was a sharper 
sense of facing anew the persisting point of their departure: the slave-holding pastoral of Imperial Brazil and the stifling moral cohesiveness of puritanical America.

The promise of reading in these last novels then is twofold - like Menard's Quixote, or the story about my yellow pug. It pledges familiarity with a state of affairs and perspectives other than our own, even when it depicts experiences akin to our own. We read because we want or need to know more and go farther, and we take pleasure in it. On the other hand, the act of reading also brings us closer to choices that embody the writer's life as a life in writing, one that has been written through the life of imagined others. Such mediation is the cornerstone of every act of reading - and particularly of reading narrative fiction. It is furthermore the predicament of an active life in criticism. In the case of our writers, one question immediately follows. When considering James and Machado side by side, how can we avoid making one of them the standard for approaching the other?

Traversing North and South, English and Portuguese, Old and New Worlds might indeed shed new light on writing and reading across the Americas in the company of transatlantic diplomats. Yet the weight of cultural distance, the inertia of national and linguistic traditions, and the unequal standing of each author in relation to a market of world literature require a short-term and manageable premise; something of a method for approaching the issue both novels seemed to have addressed at face value. Two displaced middle-aged men realize that the bulk and the best of their lives are now gone. In the process of coming to terms with it they articulate the grounds for a further awareness of distant others, real and imagined; but ultimately such grounds for a new life is not intended for themselves, for their adventure is the active and richly perceptive retreat of a moralist. This is where cosmopolitanism, plausible moral worlds, and the novel come together as an imaginative framework for bonds that are, in reality, the tangible threads of modern life.

Depending on people we do not actually know; drawing on displacement as a way of probing the self; taking others as artworks in the good and the bad sense of cherishing and collecting them; bridging linguistic and national borders; remaining open to life elsewhere - such are the tasks of our cosmopolitan diplomats, and none of them is intrinsically obvious or necessarily fruitful. However, to make sense of these scripts is to turn them into a consequential practice where analogies, comparisons, and a 
new map for old places lie ahead of the reader. Thus considered, the links between The Ambassadors and Counselor Ayres' Memorial - between James and Machado, between Brazil and the US - allow us to revisit the relevance of literary imagination for a sharper picture of our places actual and possible in modernity.

\section{Works cited:}

ASSIS, Machado de. Iaiá Garcia. Trans. Albert I. Bagby Jr. Lexington: University Press of Kentucky, 1977.

José Luiz Passos is Full Professor of Portuguese and Brazilian literatures at the University of California, Los Angeles (UCLA). He is the author of Romance com pessoas - a imaginação em Machado de Assis (Rio de Janeiro: Alfaguara, 2014) and Ruínas de linhas puras - quatro ensaios em torno a Macunaíma (São Paulo, Annablume, 1998). In 2009, he published his first novel, Nosso grão mais fino, followed by $O$ sonâmbulo amador (2014). E-mail: <jl.passos@ucla.edu> 